\title{
Management Model of Unda River in the Development of Traditional Village Based on Custom Village in Paksebali Village Klungkung Bali
}

DOI: https://doi.org/10.47175/rissj.v2i4.310

\section{| I Made Suwitra ${ }^{1}$ | I Wayan Subawa ${ }^{2}$ | Diah Gayatri Sudibya ${ }^{3}$ | | I Wayan Arthanaya ${ }^{4}$ | Ni Putu Sawitri Nandari ${ }^{5}$ |}

\author{
1,2,3,4 Faculty of Law Universitas \\ Warmadewa Denpasar, Bali, \\ Indonesia \\ ${ }^{5}$ Faculty of Law Universitas \\ Pendidikan Nasional Denpasar, \\ Bali, Indonesia \\ 1madesuwitra27@gmail.com \\ 2sbw54@gmail.com \\ ${ }^{3}$ diahgayatrisudibya@gmail.com \\ 4arthanaya.wayan@gmail.com \\ ${ }^{5}$ sawitrinandari@gmail.com
}

\begin{abstract}
This research is intended to identify the water resources management model carried out by Paksebali Village in the development of Tourism Villages in Klungkung Regency. Water resources (SDA) managemet in the development of tourism villages through coexistence between the Customary Villages and the Dinas (state) Villages which are oriented towards empowering rural communities for community welfare. So the Paksebali Village can coexit both the legal structure and the legal substance of the use of Unda River's surface water as a water attraction, restaurant, prewed in the development of new tourist destinations in Klungkung Regency through the development of a tourism village. KEYWORDS tourism village; customary village; Unda River Bali; water resource management.
\end{abstract}

\section{INTRODUCTION}

Klungkung Regency has the smallest area compared to Regencies and Cities in Bali, which is $315 \mathrm{~km} 2$. Its area is one third $\left(112.16 \mathrm{Km}^{2}\right)$ located between the islands of Bali and two thirds $\left(202.84 \mathrm{Km}^{2}\right)$ are islands, namely Nusa Penida, Nusa Lembongan and Nusa Ceningan ${ }^{1}$. In carrying out development, it is based on the Vision: of Klungkung Superior and Prosperous ". Its implementation is based on the motto "Gema Santi" (polite and innovative community movement) which has been launched coinciding with the 108th anniversary of Puputan Klungkung.

Paksebali Village is the only village that is ready to carry out as the Tourism Village. In addition to redesigning Unda River, it has also penetrated agro tourism by creating tracking paths in the hills, utilizing natural river paths. From the hills you can enjoy the sea view, Mount Agung, Nusa Penida Island

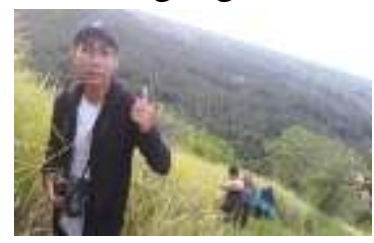

The existence of tracking in the hills is believed to be able to strengthen the status of the Tourism Village, because previously it was able to organize Unda River and build a restaurant to support the needs of tourists who do rafting. Therefore it is planned to cooperate with the travel bureau on a visit to Klungkung. The district government is expected to be present from the beginning in developing and facilitating surface water and agricultural land management as agrarian resources for new tourist destinations

\footnotetext{
${ }^{1}$ Badan Perencanaan Pembangunan Daerah, 2015, "Penyusunan Rencana Detail Desa Wisata Kamasan”, Badan Perencanaan Pembangunan Daerah Kabupaten Klungkung
} 
Referring to the background, some legal issues can be formulated as research problems, namely:

(1) How is the model of agrarian resource management by Paksebali Village as a Tourism Village in Klungkung Regency?

(2) How is the coexistence between State Law and Customary Law in the management of Agrarian Resources based on tourist villages and local legal wisdom?

\section{RESEARCH METHODS}

This type of research used is in the form of normative legal research and empirical legal research adjusted to the problem (legal issues) to be analyzed ${ }^{2}$.This type of research was chosen because on one side it is suspected that there was a duplication of legal norms related to the control of agrarian resources and authority in its management by customary or official villages and district governments as land assets or even the provincial authority in the utilization of surface water. It was also observed that there were gaps in its management by the Customary Villages and Dinas Villages related to the right to control the state which could be submitted to the Regency Government as a Self-Defense Region. The approach used is a statutory approach, historical approach, case approach ${ }^{3}$, analytic approach. .

Other approaches that are quite relevant in accordance with empirical problems will be used the anthropological law approach ${ }^{5}$, and the customary law approach ${ }^{6}$. Data obtained from the first source (primary) and second source (secondary) referred to as Legal Materials. The research location in Paksebali Village, Dawan District, Klungkung Regency is one of the villages considered capable of managing agrarian resources, namely water resources in the form of rivers known as Kali Unda River. Secondary data in the form of legal material was collected by documentation study, recording by file system ${ }^{7}$. Whereas primary data was collected through observation and interviews. Then analyzed by hermeneutic and qualitative methods ${ }^{8}$.

\section{RESULTS AND DISCUSSION}

\section{The Management of Agrarian Resoursces in Pasekbali Village through tourism village}

Tourism village is a form of integration between attractions, accommodation and supporting facilities that are presented in a structure of community life that integrates with the applicable procedures and traditions. This was conveyed by Nuryanti ${ }^{9}$. Tourism village is currently made a breakthrough by all regencies in Bali, such as Klungkung.

The settlement of Tourism village is also one of the invation of regency to find osubstitution alternative, such as Gianyar Regency, which intensively establishes tourism

\footnotetext{
${ }^{2}$ Ronny Hanitijo Soemitro, 1983, Metodelogi Penelitian Hukum, First Printing (Jakarta: Ghalia Indonesia, 1983), p. 15.

${ }^{3}$ Peter Mahmud Marzuki, Penelitian Hukum, First Printing, (Surabaya: Fajar Interpratama, 2005). p. 93.

${ }^{4}$ Johnny Ibrahim, Teori dan Penelitian Hukum Normatif, Revised Edition, Second Printing, (Malang Jawa Timur: Bayumedia Publishing, 2006), p. 98.

${ }^{5}$ Nader, Laura and Harry F. Todd, Jr., The Disputing Process Law in Ten Societies, (New York: Columbia University Press, 1978), p. 2.

${ }^{6}$ R. Soepomo, Hubungan Individu dan Masyarakat dalam Hukum Adat. Four Printing. (Jakarta: Pradnya Paramita, 1983), p. 32.

${ }^{7}$ I Made Suwitra, "Eksistensi Hak Penguasaan dan Pemilikan Atas Tanah Adat di Bali Dalam Perspektif Hukum Agraria Nasional, Dissertation, Universitas Brawijaya, Malang, 2009, p. 51.

${ }^{8}$ Jazim Hamidi, Herneneutika Hukum, Teori Penemuna Hukum Baru dengan Interpretasi Teks, First Printing, (Yogyakarta: UII Press, 2005), p. 45.

${ }^{9}$ Nuryani Wiendu, 2017, "Concept, Perspective and Challangs”, Paper, Accessed on December 21, 2017
} 
village as the sluggishness of Sukawati Art Market, which used to be one of the min sources of regional income. There are two main concepts in the Tourism Village component, namely:

1. Accommodation, means part of the residence of local residents and/or units that develop on the concept of residence of the population.

2. Attraction, means the entire daily life of the local population along with the physical setting of the village location which allows integration of tourists as active participation such as dance courses, languages and other specific

Direct interaction of tourists is possible to stay/spend the night in accommodation owned by that village. The impact can be controlled by various considerations, namely the carrying capacity and potential of the local community. Another alternative to this model is the incorporation of the first and second models (UNDP and WTO 1981 Tourism Development Plan for Nusa Tenggara, Indonesia)

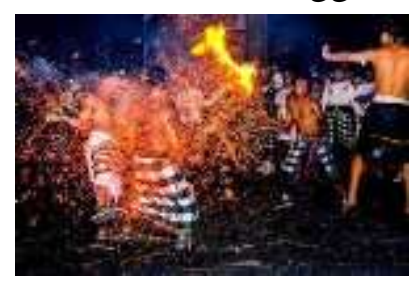

Traditional attractions that still exist, namely Ttari Lente, Lukat Geni, Dewa Mesraman, which was held during the Piodalan (Hari Raya Kuningan) in Pura Timbrah. In addition, there are also Ngelawang with Barong Bangkung and Rangda which are carried out by young people to welcome Galungan and Kuningan. In the field of agrarian resources there is a water source in Taman Seganing Temple which is used for the source of Holy Water (Tirta) and "Melukat" to eliminate all the "Mala" (inner impurities) in humans. Water attractions that have also been developed are through the arrangement of Unda River as a new destination

The Klungkung Tourism Office stated that there were 18 locations of Tourism Villages in Klungkung Regency in 2016. The formation was very close to the potential of the village concerned and was expected to be able to boost the economy of the community. Of the 18 new tourist village locations, some that appear to have evolved like the Paksebali Village, because it really depends on the quality of the human resources managing it.

Each village is expected to be able to explore its potential. Both natural wealth and local wisdom. So the potential attraction must be raised. The development of a Tourism Village also needs the support of the Tourism Awareness Group (Pokdarwis), because its existence is not evenly distributed. At present the growth is being boosted by the Regional Government. The goal is that the management of objects becomes more maximal and sustainable. ${ }^{10}$

Other attractions that are being developed are opening tracking pathway in the hills including Mandean Hill, Bukit Tangkit Putih and Bukit Mas which will be able to display views of the sea, Mount Agung, Nusa Penida Island, and natural paddy fields. Besides that, Gasebo is prepared as a place to rest / relax tourists who are tracking.

The management in the form of the utilization and use of Agrarian Resources in an integrated manner in the Tourism Village is relevant to the determination and international award obtained by Bali in 2017, which is one side won the World's Best Destination. While on the other side also managed to get the latest award from the TripAdvisor Traveler Choice Award which was announced in March 2017 to get rid of 418 other leading destinations around the world. As stated by the Deputy of Tourism Marketing Development Abroad, Ministry of Tourism I Gde Pitana.

According to Head of Destination Marketing for TripAdvisor Asia Pacipic Sarah Mathews said the award winners were selected based on reviews and opinions made by

\footnotetext{
${ }^{10}$ Bali Post, "Pengembangan Desa Wisata terkendala SDM", 7 Agustus 2017, p. 10.
} 
tourists around the world in a period of 12 months using an algorithm that takes objectively the quality and quantity of reviews ${ }^{11}$

Of those two awards, Bali will be better known and predicted to experience an increase in the number of tourist visits. This condition will be really relevant to be utilized by the existing village government in each Regency/city in managing their agricultural resources in an integrated manner in the Tourism Village container with the aim of improving the welfare of the people or villagers in the concept of community empowerment.

Agrarian Resources intended here include land, water especially surface water such as river water. Whereas the Management Right was born due to the development of an area. In fact many offices in urban areas use land with management rights. ${ }^{12}$ This condition is according to Parlindungan relevant to the provisions of Article 2 Paragraph (4) of the Basic Agrarian Law (BAL) which formulates:

The ruling right from the State can be empowered by the autonomous regions and customary law communities, only as necessary and not in against with national interests, according to the provisions of Government Regulations

Historical management rights are not a given name by BAL, but as a translation from the Dutch "Berheersrecht" = "Mastery". Judicially, the Right to Control is then regulated in Government Regulation Number: 8 of 1953 concerning the Control of State Land Rights. The meaning of tenure rights in this PP contains, namely:

a. Plan, designate, use of the land;

b. Use the land for the purpose of carrying out its duties;

c. Receive income / compensation or annual compulsory money.

As a follow-up to Government Regulation No. 8/1953, then issued Minister of Agrarian Decree No. Decree VI / 5 / Ka dated January 20, 1962 which formulates: Establish as rights in addition to ownership rights, land use rights and building rights to be registered according to the provisions of PP 10 of 1961 (LN of 1961 No. 28).

(1) Right of ownership (berheer) by a Department, Office or Self-Defense Region on land controlled directly by the State, based on PP number 8 of 1953 (LN of 1953 No. 14 ) or other statutory regulations before the enactment of said PP.

(2) Right to use for a period of more than 5 years, with the understanding that if the time period is not specified, then it is considered as more than 5 years.

The subject of rights is the local government, BUMN (State Owned Enterprises), and BUMD (regional-Owned Enterprises0. This management right can only be on state land which is controlled by a government agency, BUMN, and BUMD. On the Management Right, other rights can still be given such as Right to Build (HGB), Right to Use (HP) on behalf of other legal entities or individuals, based on the agreement with the BUMN/BUMD 13.

The development of world tourism from year to year shows a very rapid development, which is caused, namely, by changes in the socioeconomic structure of countries in the world and more people who have higher incomes. In addition, tourism has developed into a global phenomenon, a basic need, and a part of human rights that must be respected and protected. The Government and Regional Governments, tourism businesses, and the community are obliged to ensure that travel as a right of everyone can be affirmed so as to support the

\footnotetext{
${ }^{11}$ Bali Post, Bali raih World's Best Destination, Sabtu, 22 April 2017, p. 18.

${ }^{12}$ Supriadi, 2012, Hukum Agraria, Cetakan ke lima, Sinar Grafika, Jakrata, p. 148.

${ }^{13}$ Bernhard Limbong, 2014, Politik Pertanahan, Pustaka Margaretha, Jakarta, p. 61.
} 
achievement of increased human dignity and dignity, increased prosperity, and friendship between nations in order to realize world peace. ${ }^{14}$

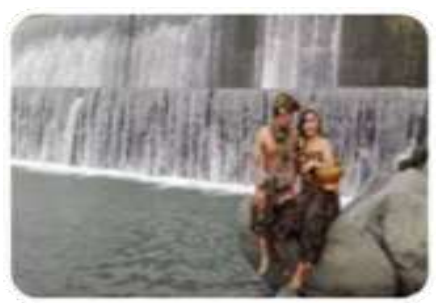

Unda River is the western boundary of Paksebali Village. The water of Unda River after being made a kind of dam which is often called the "Dam" functions to distribute water to each Subak in Klungkung and Dawan Districts. Initially the water that has been dammed through the "Dam" as a stretch of water with various types of rocks left just like that. However, as an agrarian resource, it is an extraordinary potential that can be explored and developed by the community, individually or institutionally, to obtain economic benefits. However, the ability to see that potential was seen not by the surrounding community, but by others who initially used it as a regular photo background, and then developed for prewed photos like the picture above.

Observing the increasing number of visits by the community to utilize the Kali Unda River water flow which is like a curtain, the Village Government has begun to organize by

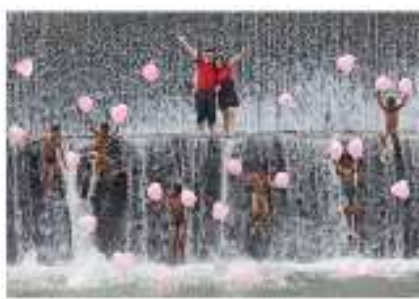
providing a parking space, building a restaurant, a children's playground. From this arrangement, the village gets income through charging tourist attraction fees from each visito

This arrangement was carried out by keeping in mind, that almost all villages in Bali now beautify themselves for tourism. The Paksebali Village is no exception, continuing to explore and exploit the potential of its village. As a tourist village. As a media for publication and documentation of the existence of the Paksebali Tourism Village, galvanized Paksebali Tourism Village has been installed on a cliff wall of approximately 20 meters.

The Regent appreciated all the efforts to develop tourism facilities in Paksebali Village, which has been able to attract many tourists. The Regent also acknowledged the success of the Paksebali Village Perbekel in exploring and exploiting the potential of the village and managing it based on the Village Regulation (Perdes) through the BUMDes (Village-Owned Enterprises), so as to increase PAD (local income)

The next step, through the regency government, has sent a letter of request for structuring assistance to the Bali Penida Regional Water and River Agency to arrange some remaining space around the Unda river,". The Regent of Klungkung hopes that all villages can follow in the footsteps of Paksebali Village. According to him, with a large enough village fund, there is no reason for the village not to develop its potential in the form of agrarian resources, traditions, arts, crafts and local communities

Meanwhile, the Paksebali Village Perbekel (village Head) expressed its gratitude for the support of the Klungkung Regency Government which helped drive the enthusiasm of village officials and residents to develop tourism in his village. Thanks to the development of tourism, his village received a minimum income of $\mathrm{Rp} 3$ million per month. "There is still land that can be cultivated and developed. The hope is that the district government is willing to help him.

The model of management of agrarian resources, traditions, arts and crafts in supporting development as a Tourism Village is carried out by the Village Government Office (Keperbekelan) through the Village Owned Enterprises (BUMDes) formed based on Village Regulations (Perdes) jo Klungkung District Regulation Number 12 Year 2010 jo

\footnotetext{
${ }^{14}$ Ibid, p. 422.
} 
Minister of Domestic Affairs Regulation Number 39 of 2010 concerning Village-Owned Enterprises. In Article 1 number 6 is formulated:

Village-Owned Enterprises, hereinafter referred to as BUMDes, are village businesses formed/established by village governments whose capital ownership and management are carried out by the village government and the community.

As a follow-up to this Ministerial Regulation, the Minister of Village, Underdeveloped Regional Development, and Transmigration of Republicof indonesian Regulation No. 4 of 2015 concerning the Establishment, Management and Management, and Dissolution of Village-Owned Enterprises, which mandates the formation of Village Regulations (Perdes) for the establishment of BUMDes such as regulated in Article 5 paragraph (3):

The results of the Village Deliberation agreement as referred to in paragraph (1) become a guideline for the Village Government and the Village Consultative Body to establish a Village Regulation concerning the Establishment of a Village BUM Desa (Village-owned Enterprises).

BUMDes Owned by the village have the duty to manage village-owned business units integrated with rural communities. The success of the BUMDes business can be measured from the aspect of the benefits received and felt by the village community, especially in the empowerment of human resources and increasing business income owned by the community such as small businesses in the field of crafts, waste management, parking attendants, food stalls (restaurants). Until now BUMDes management can be felt by the village community. The progress of the BUMDes is determined by the integrity of the Perbekel as the Village Head who is in charge of the Village Government. This means that the commitment of Perbekel as the Village Head to advance the Village in accordance with the Vision and Mission will be tested from his ability to increase the potential of the village and the potential of the community to become more independent and the ability to value it for sustainability

\section{Coexistence of State Law and Customary Law in the Management of Agrarian} Resources Based on Tourism Villages

In Bali there is known duality of government systems, namely the Desa Dinas (State Village) and Desa Adat Customary village). Paksebali Village as a Service Village (Keperbekelan) consists of 5 (five) Banjar Dinas (State), namely the Kanginan Banjar Dinas, Kawan Banjar Dinas, Peninjoan Banjar Dinas, Bucu Banjar Dinas and Timbrah Banjar Dinas and are divided into 8 (eight) Banjar/Pesamuan, namely Banjar Kanginan, Banjar Kawan, Banjar Peninjoan, Banjar Timbrah, Banjar Bucu, Pesamuan Puri Satria Kawan's, Pesamuan Puri Satria Kaleran and Pesamuan Puri Satria Kanginan. The eight Banjars/Pesamuan are also called the Banjar Adat which is affiliated in the Sampalan Customary Village. So these eight Indigenous Banjars are administratively administered by the Dinas Desa (state village) administration in five Dinas/Dusun Banjars. This means that there are two Banjar Adat who are members of one Dusun.

Paksebali village through the establishment of a number of businesses in BUMDes has been able to reduce poor households (Chairman of BUMDes revealed that this business entity was formed in 2014 which now has 5 (five) businesses, namely: waste management units, drinking water units, savings and loans, tourism units, markets that are developed gradually adapted to the potential of the village.

Through the savings and loan program for small and medium Enterprises (SMEs) and industries such as weaving, prada, klangsah and ingka are growing. Its existence is also able to provide employment, such as in market units, transport workers carried out by residents 
who were previously unemployed. The impact is very good for developing villages. Labor is absorbed, the economy moves, he stressed

According to Perbekel (Village Head), BUMDes has 35 employees so it is considered to be very strategic in alleviating poverty. Sustainable economic movements are able to provide space for Poor Households to find income that leads to increased welfare. Previously the poverty number was 202 families, now only 44 are alleged as one of the positive impacts of the BUMdes.

The Head of the Community and Village Empowerment Service, Population Control and Family Planning of the Klungkung Regency stated that the Paksebali BUMDes had developed and were able to contribute in accelerating development in the village. For this reason, Human Reseources must be maximized through training activities on a regular basis. Capital affairs directly from the village concerned plus injections from the Provincial Government of Bali, while from the Regency are still zero. For capital there is an independent.

Observing the management of agrarian resources and other local potentials in the village in developing the Tourism Village, it can be interpreted that the BUMDes as a business unit owned by the Village has a very strategic role. The developed local potentials are also inseparable from the role of outsiders who find and at the same time give a clue, that agrarian resources such as Unda River water, Seganing Temple Toya, hills and traditional arts owned by Pura Timbrah have a sale value for the welfare of the local community which is packaged through the Tourism Village.

Unda River's water management rights, known as the "Tirai Air berundag"", were originally based on Ulayat Rights (Prabumian Rights). Objects of Customary Rights, namely: land (land), water (waters such as rivers, lakes, beaches and their waters), wild plants (fruit trees, trees for carpentry wood, or firewood), wild animals. ${ }^{15}$ The customary law community as the owner of customary rights in Bali is called Desa Adat. Development of Balinese culture is indirectly carried out by the Indigenous Village. Through the Desa Adat, all forms of physical building artifacts of the Pura (Hindu holy place) can be preserved including all kinds of culture such as all arts integrated with the implementation of religious ceremonies at the Temple.

In the implementation of state law, the business units owned by Paksebali Village are BUMDes which manage customary land and padruwen (belonging) to Indigenous Villages such as Unda River water, Seganing Temple water source, Timbrah Temple by sharing its traditional arts attractions, hills, Home Stay in the Pekarangan Village (PKD) and other artistic attractions. This is where there needs to be a coexistence between State law and customary law as people's law so that the legal objectives are achieved, namely certainty, justice, and expediency (benefit to the welfare of the village community) in accordance with the Paksebali Village Vision: "The realization of the "Paksebali Village" which RAMAH (Acronym: Rukun, Adil, Makmur, Aman, dan Harmonis) based on Tri Hita Karana ". Therefore, in the utilization of surface water, it is co-existent with the Regional Regulation of the Province of Bali Number: 3 of 2004 concerning Taxes on the Extraction and Utilization of Ground and Surface Water in order to create order in the utilization for sustainability.

The intended coexistence is the operation of the State law created by the Village Government to the Central Government together with the Customary law as the Folk Law, bearing in mind the existence of the customary rights of the Customary Villages in Bali must be recognized and respected by the State and its Government because they still exist. Legally

\footnotetext{
${ }^{15}$ Sorojo Wignjoadipuro. (1979). Pengantar dan Azas-azas Hukum Adat, Alumni, Bandung, p. 249.
} 
the existence of customary law communities and their customary rights as traditional rights is recognized and respected based on the 1945 Constitution of the Republic of Indonesia, Act Number 5 of 1960 concerning Basic Regulations on Agrarian Principles, Regulation of the Minister of Internal Affairs/Head of the National Land Agency Number 5 of 1999 concerning Settlement Guidelines The Issue of Customary Rights of the Customary Law Community, Minister of Agrarian and Spatial Planning/Head of BPN Number 276 / KEP19.2 / X / 2017 concerning the Appointment of Pakraman Village in Bali Province as the Subject of Common Land Rights (Communal) on Land, Domestic Ministerial Decree Number : SK.556 / DJA / 1986 concerning the Appointment of Temples as Religious Legal Entities That Can Have Property Rights.

Through the concept of Coexistence, management of agrarian resources and other local potentials by BUMDes can be carried out together under the legal umbrella of "Cooperation" by co-existing between institutions (legal structures), between laws (legal substance), and between the authority of the Desa Desa and the Desa Adat . The aim is to guarantee legal certainty, justice and benefits (welfare), that is, relevant to the mandate of Article 33 paragraph (3) of the 1945 Constitution of the Republic of Indonesia which formulates: "The earth and water and natural resources contained therein are controlled by the State and are used for -the magnitude of people's prosperity ".

The legal structure in question is the administration of the Paksebali Village with the administration of the Sampalan Adat Village through eight Banjar Adat officers in the administrative area of the Paksebali Village, so that through the legal umbrella the cooperation of the business unit as a business unit managed by the BUMDes also provides opportunities for business units owned by Indigenous Villages such as LPD (Village Credit Institutions) to move forward together. The strength of this concept of coexistence is in the human resources of the Paksebali Village which is also the Krama of the Adat / Banjar Adat villages, so that empowerment activities through HR training are also an effort to strengthen the Adat Village HR.

From the legal aspect, the substance of legal norms in Awig-Awig of customary Village must not be in conflict with State law. Likewise, the Village Regulation (Perdes) drawn up by the Paksebali Village must not deny the provisions in the Awig-Awig of customary Village. Whereas the exercise of authority of each village government is carried out through coordination, so that the existing security system in the Dinas Desa and Adat Village can strengthen each other in tasks, such as the synergy between the Hansip and Pecalang tasks during the Election, the celebration of religious holidays, parking arrangements, Police Officers with Pecalang in traffic arrangements during traditional ceremonies. Likewise in controlling population there is a synergy between Polmas (Village Police), Babinsa (Village Army), and Pecalang.

This coexistence model was developed keeping in mind the recognition of the existence of indigenous and tribal peoples and their traditional rights. Likewise, the integration of the concept of village community empowerment in order to be able to compete and increase its sustainability in global conditions by utilizing local potentials of international scale In addition, the development of a coexistence model is intended to establish harmonious relations between the village, district and provincial governments in a modern autonomy, not ansich autonomy. This coexistence is very possible by referring to the goal of regulating agrarian resources is the welfare of citizens. It is relevant to what Bentham stated through his Utility theory, which puts benefits as the main objective of law. Utilization is defined as happiness. So whether it's good or bad, whether or not a law depends on whether the law gives happiness to humans or not. This happiness should be felt by every individual. But if it is not possible (and certainly not possible), it is sought that happiness is enjoyed by as 
many individuals as possible in the community (the nation) (the greatest happiness for the greatest number of people).

The Village Administration of the Office (Keperbekelan) and the administration of the Customary Village in duality harmony cannot be denied in Bali, because the existence of a customary village cannot be denied by remembering that the success of development in Bali was due to the support of the Customary and Prefectural Village manners. Besides that, Krama Adat Village is a unity as a member of the people of Keperbekelan Village, it's just differentiated in its function, which is an administrative function and a religious social function.

\section{CONCLUSION}

From the discussion it can be concluded, that Agrarian Resources and other local potential are managed in an integrated manner through BUMDes as a business unit of Paksebali Village so that it is relevant to the concept of Tourism Village developed in Klungkung Regency. And with the duality in the village government system as one of the characteristics of Bali's differentiation the implementation of the concept of "Coexistence" has basically taken place in the management of all attractions in supporting the sustainability and sustainability of the Tourism Village, because it has now been able to improve the welfare of the community and vice versa has succeeded in reducing the number of Houses Poor Ladder (RTM) in the Village.

\section{Recommendation}

Even so it is considered necessary to give some recommendations, namely: management of agrarian resources and other local potentials in the development of sustainable Tourism Villages need to be recognized as customary rights known as padruwen villages (owned by Adat Villages) can be done together in a coexistence context by referencing religious communal values and the principle of deliberation and mutual cooperation in global developments while still paying attention to aspects of certainty, fairness and expediency.

\section{REFERENCES}

Regional Development Planning Agency. (2015). "Compilation of detailed plans for Kamasan Tourism Village", Klungkung Regency Regional Development Planning Agency.

Bernhard Limbong. (2014). Land Politics, Reader Margaretha, Jakarta.

Darji Darmidiharjo and Shidarta. (1996). Principles of Legal Philosophy, Second Printing, Revised Edition, PT. Gramedia Pustaka Utama, Jakarta.

Jazim Hamidi. (2005). Legal Herneneutics, The Theory of New Law Enforcement Users with Text Interpretation, First Printing, UII Press, Yogyakarta.

Johnny Ibrahim. (2006). Theory and Research on Normative Law, Revised Edition, Second Printing, Bayumedia Publishing, Malang East Java.

Nader, Laura and Harry F. Todd, Jr. (1978). The Disputing Process Law in Ten Societies, Columbia University Press. New York.

Nuryani Wiendu. (2017). "Concept, perspective and challangs", Paper, accessed on December 21, 2017.

Peter Mahmud Marzuki. (2005). Legal Research, Prints I. Fajar Interpratama, Surabaya.

Ronny Hanitijo Soemitro. (1983). Ronny Hanitijo Soemitro, 1983 Legal Research Methodology, First Matter, Ghalia Indonesia. Jakarta.

Soepomo, R. (1983). Relationship of Individuals and Society in Customary Law. 4th printing. Pradnya Paramita. Jakarta. 
Surojo Wignjodipuro. (1979), Introduction and Principles of Customary Law, Alumni, Bandung.

Supriadi. (2012). Agrarian Law, 5th edition, Sinar Grafika, Jakarata.

Suwitra, I Made. (2009). "The Existence of the Right of Ownership and Ownership of Customary Land in Bali in the Perspective of National Agrarian Law", Dissertation, Postgraduate Doctoral Law Program, Faculty of Law, Universitas Brawijaya, Malang

\section{Regulations}

The 1945 Constitution of the Republic of Indonesia.

Law Number 6 of 2014 concerning Villages, State Gazette of the Republic of Indonesia of 2014

Number 7, Supplement to the State Gazette of the Republic of Indonesia Number 5495.

Act of the Republic of Indonesia Number 28 of 2009 concerning Regional Taxes and Regional Levies.

Act of the Republic of Indonesia Number 5 of 1960 concerning Basic Regulations on Agrarian Principles.

Minister of Domestic Affairs Regulation Number 39 of 2010 concerning Village-Owned Enterprises.

Regulation of the Minister of Villages, Development of Undedeveloped Areas, and RI Transmigration Number 4 of 2015 concerning Establishment, Arrangement and Management, and Dissolution of Village-Owned Enterprises.

Regulation of the Minister of Home Affairs / Head of BPN Number 5 of 1999 concerning Guidelines for Settlement of the Customary Rights Rights of the Customary Law Community.

Decree of the Minister of Agrarian Affairs and Spatial Planning / Head of BPN Number 276 / KEP-19.2 / X / 2017 concerning the Appointment of Pakraman Village in the Province of Bali as the Subject of Common Land Rights (Communal).

Decree of the Minister of Domestic Affairs Number: SK.556 / DJA / 1986 concerning Appointment of Temples as Religious Legal Entities That Can Have Ownership Rights over Land.

Regional Regulation of the Province of Bali Number 3 of 2004 concerning Taxes for Taking and Utilizing Underground and Surface Water.

Bali Provincial Regulation Number: 4 of 2019 concerning Customary Villages in Bali. 